\title{
Yellow Fly, Diachlorus ferrugatus (Fabricius) (Insecta: Diptera: Tabanidae) $)^{1}$
}

G. B. Fairchild, H. V. Weems, Jr. and T. R. Fasulo²

\section{Introduction}

In Florida, the name "yellow fly" is commonly used to describe a group of about a dozen different yellow-bodied biting flies in the Tabanidae family. However, Florida tabanid experts recognize only one species, Diachlorus ferrugatus (Fabricius), as the "true" yellow fly. (Cilek 2000a). In Belize this species is known as the "doctor fly."

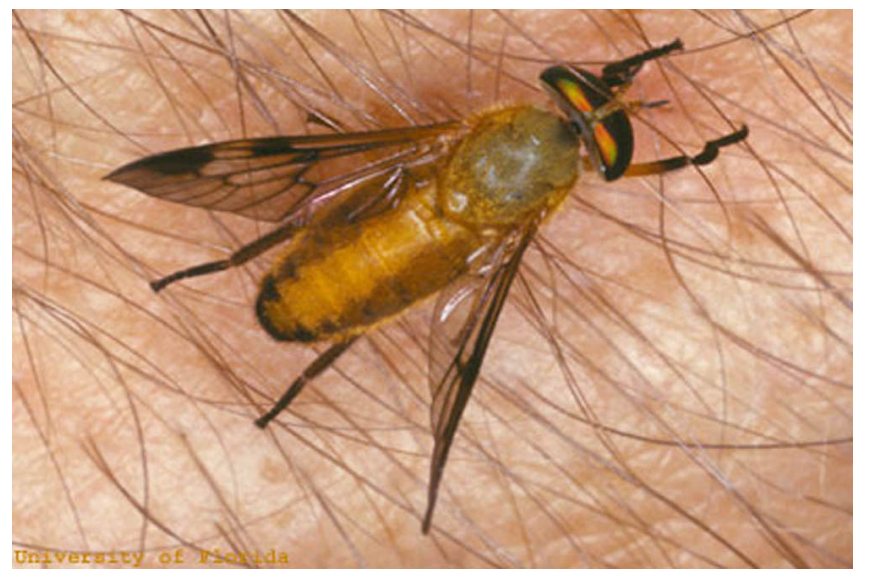

Figure 1. Adult yellow fly, Diachlorus ferrugatus (Fabricius). Credits: Photograph by: J.L. Castner, University of Florida
The yellow fly is a fierce biter. Like mosquitoes, it is the female fly that is responsible for inflicting a bite. The males are mainly pollen and nectar feeders. Tabanids are most likely encountered in hot summer and early fall weather. They are active during daylight hours.

\section{Synonymy}

Chrysops ferrugatus Fabricius, 1805: 111. Type locality: Carolina, U.S.A. Type female: lost.

Tabanus americanus Palisot de Beauvois, 1819: 222 (preocc. Forster, 1771).

Diabasis ataenia Macquart, 1838: 156. Type locality: Carolina, U.S.A.

Chrysops convergens Walker, 1848:198. Type locality: Honduras.

Chrysops approximans Walker, 1848: 198. Type locality: Florida.

1. This document is EENY-320 (originally published as DPI Entomology Circular 139), one of a series of Featured Creatures from the Entomology and Nematology Department, Florida Cooperative Extension Service, Institute of Food and Agricultural Sciences, University of Florida. Published: April 2004. This document is also available on Featured Creatures Website at http://creatures.ifas.ufl.edu. Please visit the EDIS Website at http://edis.ifas.ufl.edu. Additional information on these organisms, including many color photographs, is available at the Entomology and Nematology Department website at http://entnemdept.ifas.ufl.edu/.

2. G. B. Fairchild, H. V. Weems, Jr., Florida Department of Agriculture and Consumer Services, Division of Plant Industry; and T. R. Fasulo, Department of Entomology and Nematology, University of Florida, Gainesville, FL.

The Institute of Food and Agricultural Sciences (IFAS) is an Equal Employment Opportunity - Affirmative Action Employer authorized to provide research, educational information and other services only to individuals and institutions that function without regard to race, creed, color, religion, age, disability, sex, sexual orientation, marital status, national origin, political opinions or affiliations. For information on obtaining other extension publications, contact your county Cooperative Extension Service office. Florida Cooperative Extension Service / Institute of Food and Agricultural Sciences / University of Florida / Larry R. Arrington, Interim Dean 
Tabanus rondanii Bellardi, 1859: 68. Type locality: Mexico.

\section{Distribution}

Southeastern U.S. from New Jersey to Texas; Bahamas; Mexico to Costa Rica. The genus Diachlorus contains 23 neotropical species, as keyed by Fairchild (1972). But Diachlorus ferrugatus (Fabricius) is the only species that has reached the U.S., probably coming by way of Mexico. Its occurrence in the Bahamas seems to be a recent extension from Florida, as it has not been found elsewhere in the West Indies.

\section{Description}

Adults: The adult is a predominantly yellow fly about $1 \mathrm{~cm}$ (3/8 inch) long, similar in appearance to a deer fly (Chrysops). The fore legs are predominantly black, the other pairs yellow. The wings are clear, with black stigma, yellow costal cell, and a prominent brown patch at the apex. The eyes of the live fly are brilliant blue- green, with two semicircular purple bands. The female can be distinguished from deer flies by the very narrow frons (space between the eyes in front), and (in both sexes) the brown wing patch at the apex, rather than across the middle of the wing. The abdomen is yellow, black- haired on the sides, but with a broad yellow-haired stripe down the middle.

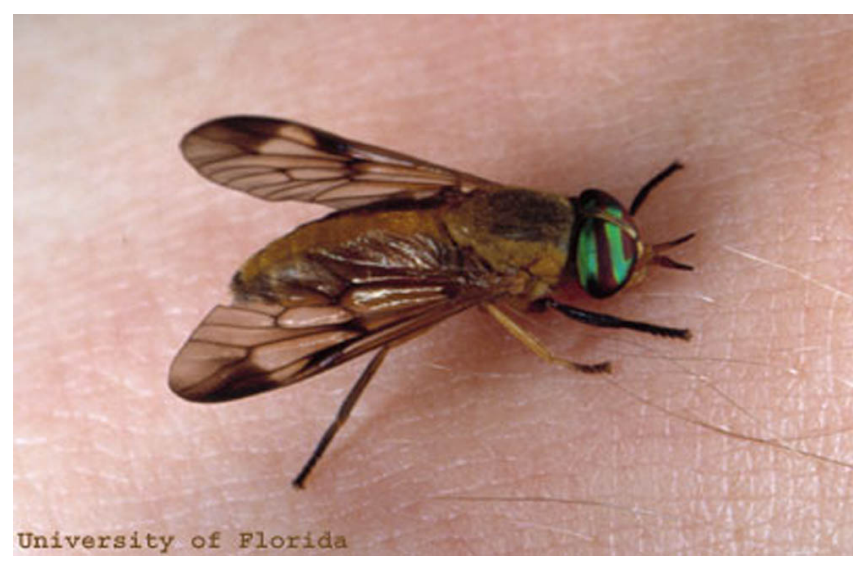

Figure 2. Adult yellow fly, Diachlorus ferrugatus (Fabricius). Credits: Photograph by: J.F. Butler, University of Florida

Eggs: The eggs are very small (about 1/16" long) and creamy white when first deposited, but turn dark after several hours. These egg masses sometimes resemble tar specks (Cilek 2000a).

Larvae: The larvae are aquatic or semiaquatic (Dame and Fasulo 2003). Larvae are slender, whitish grubs nearly covered by very fine, yellowish pubescence and bearing only three pairs of pseudopodia on each segment.

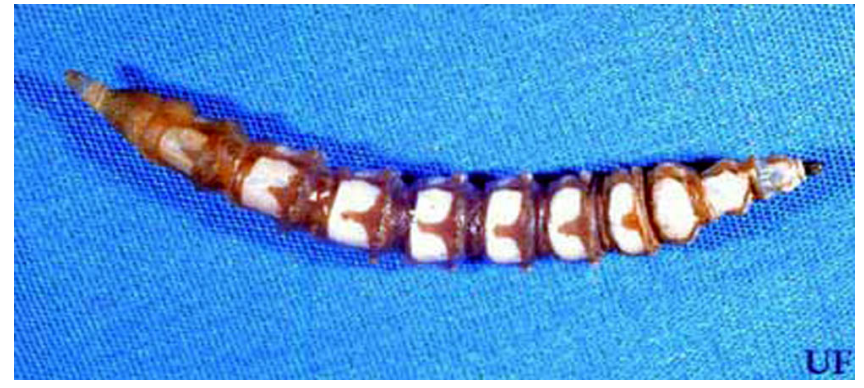

Figure 3. Tabanid larva. Credits: Photograph by: J.M. Squitier, University of Florida

\section{Life History}

Larvae feed primarily on decaying organic matter. The larvae may molt more than 10 times before pupating and emerging as adults (Dame and Fasulo 2003). Mature larvae have been collected and reared to the adult stage on a few occasions. They have been found only in deeply shaded areas in root mats of cypress, shingle oak, and other woody plants, always beneath the water surface (Jones and Anthony 1964).

Although strong fliers, adults are often found around the larval habitat, but they may move considerable distances to find a blood meal. Both sexes feed on plant nectar and pollen to obtain energy. Males rarely have been collected; most of those known were taken in light traps. The female feeds on blood to develop eggs. Mating takes place soon after emergence. Once mated, the female deposits an egg mass on plants, rocks, sticks or other similar objects usually over water or other favorable larval habitat.

Egg masses are deposited throughout the life cycle of the female. After five to 12 days, the eggs hatch and the young larvae drop into the water or mud where they feed on organic debris or prey on other small aquatic organisms (Cilek 2000a). Upon hatching, the larvae burrow into mud or moist earth 
and begin feeding. Depending upon the species and climatic region, there are usually one or two generations per year (Dame and Fasulo 2003). The winter is generally passed in the larval stage. The mature larva will grow to a size of about $1 / 2$ inch, after which it will migrate to drier soil and develop into a pupa. The pupa is a nonfeeding, resting stage that develops into the adult fly. Generally, the life cycle from egg to adult is about one year (Cilek 2000a).

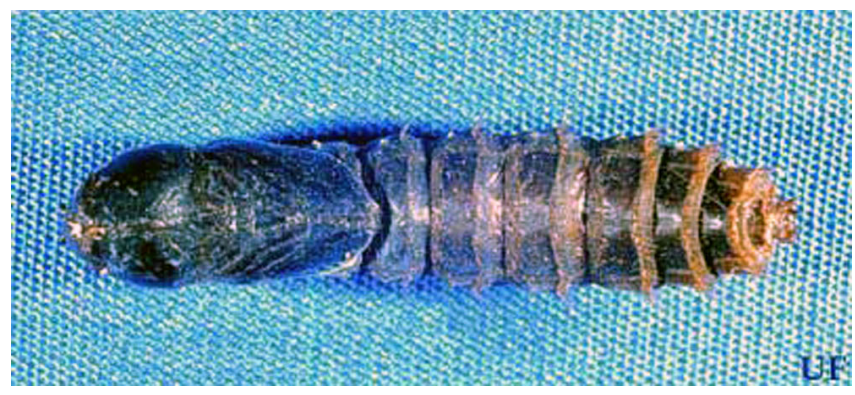

Figure 4. Tabanid larva. Credits: Photograph by: J.M. Squitier, University of Florida

\section{Biting Habits}

The female is one of the most serious biting fly pests wherever it occurs (males do not bite). It attacks man vigorously, and the bites usually are painful, causing large and persistently itching swellings in many persons. Although it attacks throughout the day, it is most active during the late afternoon and on cloudy days. It is especially common near large bodies of water, but tends to remain in or near forests, seldom attacking in numbers far from the shelter of trees. It is one of the few tabanids which attacks indoors. All exposed parts of the victim's body may be attacked, and since the flight is rather quiet, a person is not aware of the flies until the sharp pain of the bite is felt. Domestic animals, including dogs, are attacked readily, although the fly's preference for shade makes it less of a pest to cattle and horses in open pastures. Flies are on the wing in Florida from March to November, although the peak season is April through June. Williams (1971) studied biting habits of D. ferrugatus in British Honduras, but nothing comparable has been done in Florida.

\section{Management}

No effective methods for larval control are known. Mosquito repellents are moderately effective against the adults except when the flies are very abundant or very hungry. Gloves and headnets offer the only sure means of protection. We have found deet (diethyl toluamide) to be the most effective repellent. To prevent possible development of dangerous hypersensitivity and systemic reactions, persons sensitive to the bites should avoid exposure to the flies.

Currently there are no adequate means for managing populations. Traps are sometimes effective in control of small areas such as yards, camping sights, and swimming pools. Trapping of nuisance flies has reduced their numbers on the Atlantic Coast of the United States. Traps have been effective when used around cattle that are confined to manageable areas (Squitier 2003).

For additional management information see:

Insect Management Guide for Biting Flies (http://edis.ifas.ufl.edu/IG081).

\section{Selected References}

Banks N. 1904. The "yellow fly" of the Dismal Swamp. Entomological News 15: 290-291.

Bequaert J. 1924. Report of an entomological trip to the Truxillo division, Honduras, to investigate the sand-fly problem. 13th Annual Report Medical Department United Fruit Company p. 193-206.

Bequaert J. 1931. Tabanidae of the peninsula of Yucatan, Mexico, with descriptions of new species. Journal of the New York Entomological Society 39: 533-553, fig. 1.

Blickle RL. 1958. Eye color of male Diachlorus ferrugatus (Fab.). Entomological News 69: 230.

Cilek JE. (2000a). The yellow-biting flies of Florida. Ent Guide. http://pherec.org/entguides/ EntGuide1.html (5 March 2004).

Cilek JE, Medrano G. (2000b). Public perception of a trap to locally reduce yellow fly (Diptera: 
Tabanidae) nuisance in residential areas of

northeastern Florida. Florida Entomologist 83:26-30.

Dame D, Fasulo TR. (2003). Flies. Public Health

Pesticide Applicator Training Manual.

http://vector.ifas.ufl.edu/ (05 March 2004).

Fairchild GB. 1937. A preliminary list of the Tabanidae of Florida. Florida Entomologist 19: 58-63; 20: 10-11.

Fairchild GB. 1972. Notes on Neotropical Tabanidae. XII. The genus Diachlorus O.S. Florida Entomologist. 55: 219-229.

Goodwin JT. 1973. Immature stages of some eastern Nearctic Tabanidae. II. Genera of the tribe Diachlorini. Journal of the Georgia Entomological Society 8: 5-11, fig. 1-6.

Jones CM., Anthony DW. 1964. The Tabanidae (Diptera) of Florida. USDA Technical Bulletin 1295. 85 p., fig. 1-18.

Koehler PG, Short DE, Fasulo TR. (1998). Pests In and Around the Home. UF/IFAS. SW-126.

Mease JA. 1943. Deer fly desensitization. Journal of the American Medical Association 122: 227.

Philip CB. 1947. A catalogue of the blood-sucking fly family Tabanidae (horse flies and deer flies) of the Nearctic region north of Mexico. American Midland Naturalist 37: 257-324.

Shewell GE. 1947. The male of Diachlorus ferrugatus (Fab.). Canadian Entomologist 79: 32.

Squitier JM. (2003). Deer flies, yellow flies and horse flies - Chrysops, Diachlorus, and Tabanus spp. UF/IFAS Featured Creatures. http://edis.ifas. ufl.edu/IN155 (5 March 2004).

Stone A, et al. 1965. A catalogue of the Diptera of America north of Mexico. USDA Agricultural Handbook 276. 1696 p.

Williams P. 1971. Some records of Tabanidae (Diptera) from British Honduras (Belize). Journal of Medical Entomology 8: 98-107. 